Jeffrey S. Kahn, Islands of Sovereignty: Haitian Migration and the Borders of Empire.

Chicago: University of Chicago Press, 2018. 355 pp. (Paper US \$35.00)

Jeffrey Kahn's Islands of Sovereignty recounts the transformation of the Caribbean Sea from an area of mobility for Haitian nationals to a densely surveilled U.S. borderland. In the 1970s Guantánamo Harbor offered hospitality to Haitian nationals who were lost at sea, while in the 199os the Guantánamo Bay naval base was comprised of camps where Haitian exiles were detained. The aim of this groundbreaking book is to describe and analyze the development of a U.S. maritime border in the Caribbean to prevent Haitian nationals from reaching the United States. Starting with the 1981 Haitian Migrant Interdiction Operations (HMIO), a new seascape emerged, defined by U.S. policies whose enforcement covers the territorial waters of a number of Caribbean states as well as the Guantánamo naval base of Cuba. This maritime borderland is patrolled by coast guard cutters that intercept exiles' boats, expedite asylum claims, and deport all but a few claimants. Kahn, who is both an anthropologist and a legal scholar, examines the tension between liberal constitutionalism that emphasizes the rule of law and the enactment of sovereign will that led to the creation of an offshore maritime border away from legal constraints.

This complex, dense, and rich ethnography, based on two decades of fieldwork and research in state and NGO archives, offers a new conceptual approach to the study of maritime borderlands. Kahn identifies three modes of spatial organization in order to describe and analyze the "juridical-political geographies" of the Caribbean's maritime border (p. 57).

The first mode, familiar to any Caribbeanist anthropologist, legal scholar, or activist, and dubbed the "realist geography of alliance," originated in the Cold Wargeopolitical order and is based on international law. It distinguishes people who were granted asylum by the United States from economic migrants who were denied entry. Cuban nationals were categorized as political refugees while Haitian nationals, considered mere economic migrants, were deported back to Haiti without any processing of their asylum claims. The second mode of spatial organization operates along three kinds of border spaces: the territorial border, which delineates the land limits of the nation-state; the juridical border, which demarcates the areas where the federal judiciary is applicable; and the policing border, which reflects the border enforcement agents' surveilling, deterring, and detaining performances. Kahn convincingly demonstrates that if those three kinds of borderlands were aligned in the 1970s, they later diverged from each other with the extension of the policing border first into the high seas and the territorial waters of Haiti and subsequently to the areas around NEW WEST INDIAN GUIDE

(C) CATHERINE BENOÎT, 2020 | DOI:10.1163/22134360-09403004 
the Bahamas, the Turks and Caicos, the Cayman Islands, Cuba, Jamaica, and the Dominican Republic.

The conceptualization of the second mode of spatial organization is particularly illuminating for global comparisons with the externalization of the European Union's immigration policies in the Mediterranean. One wonders if such a comparison would lead to the unveiling of historical legal and political influences and discussions about extending the now-ancient territorial borders of Europe and the United States into the surrounding territorial waters. Finally, the third kind of border space refers to the legal "entry" fiction, which determines who is and who is not considered as having entered U.S. land when they arrive in an area such as a port or airport transit zone and are subjected to the discretionary power of immigration bureaucracy instead of being protected by law.

Ultimately, Islands of Sovereignty argues against traditional delineations of oceans, seas, and islands. It exemplifies the "Oceanic turn," a paradigm shift that led social scientists and writers to consider the oceans not merely as virgin liquid spaces that enabled adventurous European males to conquer the earth, but instead as places of suffering, displacements, enslavement, and coercion. This book confirms the way Caribbean islands, in this case Cuba, have become offshore sites of detention and punishment, as was the case of Manus and Maurus (where Australia implemented offshore detention centers) and the current case of Mayotte, a French territory in the Indian Ocean. As illustrated recently by Alison Mountz and Jenna Lloyd in Boats, Borders, and Bases: Race, the Cold War, and the Rise of Migration Detention in the United States, oceans and islands might be used as laboratories for experimentation in coercive policing, which can then be repatriated to the continental land.

\section{Catherine Benoît}

Anthropology Department, Connecticut College, New London CT, USA cben@conncoll.edu 